\title{
Hydrocarbon Release During Fuel Storage and Transfer at Gas Stations: Environmental and Health Effects
}

\author{
Markus Hilpert ${ }^{1} \cdot$ Bernat Adria Mora $^{1} \cdot \operatorname{Jian}_{\mathrm{Ni}^{2}} \cdot$ Ana M. Rule ${ }^{1} \cdot$ Keeve E. Nachman $^{1}$
}

Published online: 5 October 2015

(C) Springer International Publishing AG 2015

\begin{abstract}
At gas stations, fuel is stored and transferred between tanker trucks, storage tanks, and vehicle tanks. During both storage and transfer, a small fraction of unburned fuel is typically released to the environment unless pollution prevention technology is used. While the fraction may be small, the cumulative release can be substantial because of the large quantities of fuel sold. The cumulative release of unburned fuel is a public health concern because gas stations are widely distributed in residential areas and because fuel contains toxic and carcinogenic chemicals. We review the pathways through which gasoline is chronically released to atmospheric, aqueous, and subsurface environments, and how these releases may adversely affect human health. Adoption of suitable pollution prevention technology should not only be based on equipment and maintenance cost but also on energy- and health care-saving benefits.
\end{abstract}

Keywords Gas stations · Vapor emissions · Fuel spills · Adverse health effects $\cdot$ Pollution prevention

\section{Introduction}

The primary function of gas stations is to provide gasoline and diesel fuel to customers, who refill vehicle tanks and canisters.

This article is part of the Topical Collection on Air Pollution and Health

Markus Hilpert

markus_hilpert@jhu.edu

1 Department of Environmental Health Sciences, Bloomberg School of Public Health, Johns Hopkins University, Baltimore, MD, USA

2 Carey School of Business, Johns Hopkins University, Baltimore, MD, USA
Operating a gas station requires receiving and storing a sufficient amount of fuel in storage tanks and then dispensing the fuel to customers. During delivery, storage, and dispensing of fuel at gas stations, unburned fuel can be released to the environment in either liquid or vapor form. Fuel is a complex mixture of chemicals, several of them toxic and carcinogenic [1]. Of these chemicals, the health consequences of chronic benzene exposure are best understood. Occupational studies have linked benzene exposures to numerous blood cancers, including acute myeloid leukemia and acute nonlymphocytic leukemia [2]. Concerns have been raised that gasoline vapor exposures incurred by gas station attendants [3] and tanker truck drivers [4] may result in health risks.

The potential for fuel released to the environment at gas stations, in the form of liquid spills or vapor losses, to elicit adverse health outcomes could be substantial due to the widespread distribution of gas stations across communities and the intensive usage of vehicle fuel in industrialized nations. For example, the USA consumed about 137 billion gallons of gasoline, or about 430 gallons per US citizen, in 2014 [5]. If only a small fraction of this gasoline was to be released to the environment in the form of unburned fuel, for instance $0.1 \%$, then about $1.6 \mathrm{~L}$ of gasoline would be released per capita per year in the USA. In Canada, a study estimated that evaporative losses at gas stations in 2009 amounted to 58,300,000 L [6]. With a population of about 34 million, we estimated that about 1.7 $\mathrm{L}$ of gasoline was released per capita per year in Canada from evaporative losses, without counting the liquid spills. While personal intake of this quantity of gasoline would result in serious adverse health effects, environmental dilution can decrease personal exposure. An overarching question is under which conditions dilution in the aqueous and atmospheric environments can limit personal exposures to acceptable levels. For example, cumulative adverse health effects could be more pronounced in metropolitan areas where more people 
are exposed and where the density of gas stations is larger than in rural areas.

Engineers and regulators have paid a lot of attention to leaking underground storage tanks (LUSTs) and leaky piping between storage tanks and gasoline-dispensing stations, which can result in catastrophic fuel release to the subsurface [7]. For instance, double-walled tanks have become standard in order to minimize accidental release of liquid hydrocarbon. Technologies that prevent pollution due to non-catastrophic and unreported releases of hydrocarbon that occur during fuel storage and transfer (hereafter referred to as "chronic releases"), however, have not been uniformly implemented within the developed world. The state of California in the USA has the strictest policies to minimize chronic releases, either in liquid or in vapor form. Other US states and industrialized nations, however, have not uniformly adopted California's standards, potentially because comprehensive economic and public health analyses to inform policy making are not available. This paper focuses on chronic hydrocarbon releases at gas stations (including both liquid spills and vapor losses), their contributions to human exposures and potential health risks, and factors that influence the adoption of suitable pollution prevention technology.

\section{Chemical Composition of Fuel}

Fuels have historically contained significant fractions of harmful chemicals, some of which have been documented as contributing to morbidity and mortality in exposed persons. Crude oil, from which fuels have historically been refined, already contains toxic chemicals such as benzene [8]. Fuel additives including anti-knocking agents and oxygenates have historically also been a health concern [9]. Fuel composition has changed over time, primarily due to environmental and health concerns [9]. Fuel composition also depends on geographic location and fuel type (e.g., conventional versus reformulated gasoline) [10]. In the $1920 \mathrm{~s}$, lead was added to gasoline as an anti-knocking agent to replace added benzene because of its carcinogenicity [11]. Due to the massive release of lead to the environment and its neurotoxicity [12], lead was replaced in the 1970 s by less toxic anti-knocking agents including methyl tert-butyl ether (MTBE) [13]. To reduce formation of ground-level ozone and associated adverse respiratory health effects [14], cleaner burning of fuel was sought in the 1990 s by adding oxygenates to gasoline. This was accomplished by increasing the concentrations of MTBE, which acts as an oxygenate [9]. However, MTBE accidentally released to the subsurface [15] contaminated downstream drinking water wells relatively quickly, moving almost with the speed of groundwater, because MTBE is hydrophilic and poorly biodegradable [16]. MTBE was later on identified as a potential human carcinogen [16]. In the USA, MTBE was therefore phased out in the 1990s; at the same time, refineries began supplementing fuel with ethanol as an oxygenate [17].

In current gasoline formulations, benzene, toluene, ethylbenzene, and xylene (BTEX) and particularly benzene are the most studied chemicals and are currently believed to be of greatest health concern [18]. Table 1 shows that fuels have historically contained large fractions of toxic and carcinogenic chemicals. In many countries, lead and MTBE are no longer used. Benzene levels in gasoline are currently much lower in most countries (e.g., on average $0.62 \%$ by volume in the USA), though the chronic health effects of benzene and other BTEX chemicals at relevant exposure levels are not well understood.

\section{Chronic Release and Environmental Transport of Contaminants from Fuel}

At gas stations, fuel can be released in both liquid and vapor phases during delivery, storage, and dispensing. Direct vapor release is usually associated with atmospheric pollution, while liquid spillage is commonly associated with soil and groundwater contamination. However, spilled liquid fuel also evaporates into the atmosphere. Hypothetically, hydrocarbon vapors can also condense back into liquid form; however, this appears to be unlikely due to quick dilution in a typically turbulent atmosphere. Figure 1 depicts how releases of unburned fuel contaminate the atmospheric, subsurface, and surface water environments (omitting LUST and leaky piping as well as marine gas stations which may release fuel directly to surface water).

\section{Liquid Fuel Spills}

Liquid fuel spills at the nozzle have received less attention than liquid releases due to LUSTs. These fuel spills occur when the dispensing nozzle is moved from the dispensing station to the vehicle tank and vice versa, when the automatic shutoff valve fails, due to spitback from the vehicle tank after the shutoff has been activated, and when the customer tops off the tank.
Table 1 Historical content of non-negligible amounts of toxic and carcinogenic chemicals in fuel

\begin{tabular}{lll}
\hline Chemical of concern & Fraction & Health effects \\
\hline Benzene & Up to $5 \%$ [75] & Carcinogenic [2] \\
Lead & Up to 2 g per gallon [76] & Central nervous system [12] \\
MTBE & Up to $15 \%$ [77] & Potential human carcinogen [78]
\end{tabular}




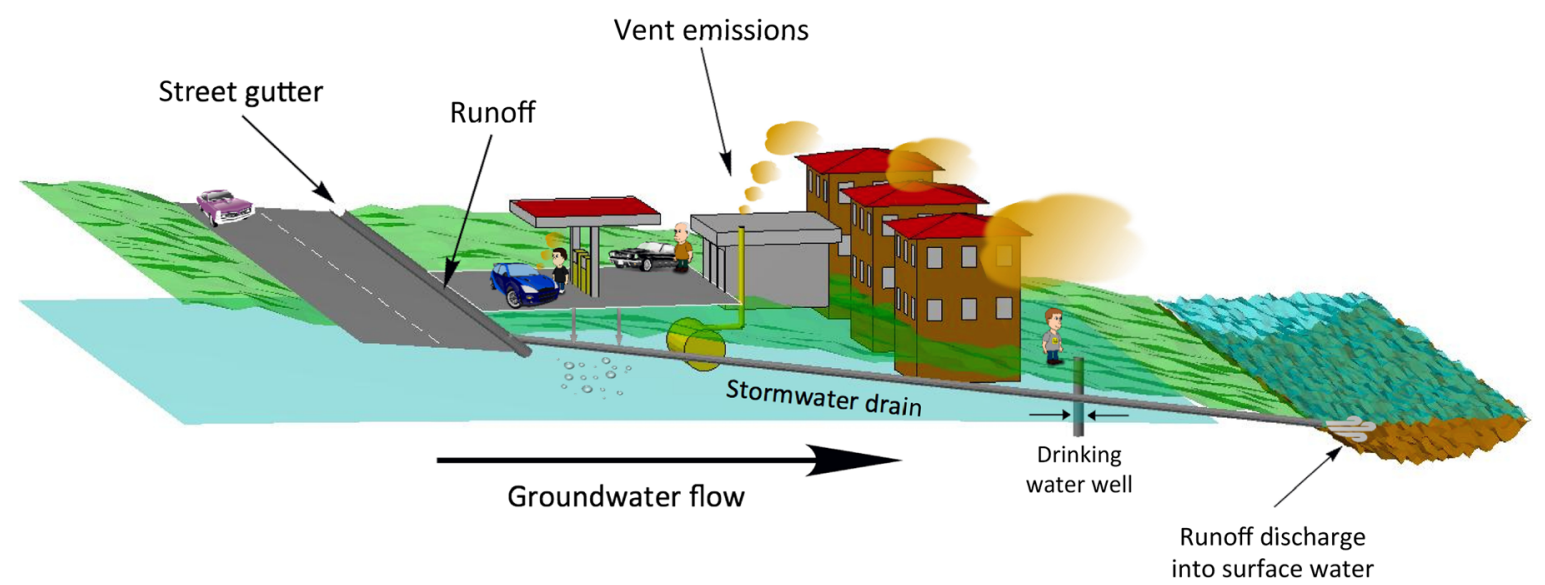

Fig. 1 Gas stations are embedded into the natural environment and can consequently release pollutants to the atmosphere, the subsurface including soil and groundwater, and surface water

In a study quantifying fuel spill frequencies and amounts at gas stations in California, about $6 \mathrm{~L}$ of gasoline was spilled per 16,200 gallons of gasoline dispensed at gas stations without stage II vapor recovery compared to $3.6 \mathrm{~L}$ at gas stations per 14,043 gallons of gasoline dispensed at gas stations with stage II vapor recovery (at the nozzle) [19]. This would mean that about 0.007 and $0.01 \%$ of dispensed gasoline are spilled in liquid form during vehicle refueling at gas station with and without stage II recovery (numbers calculated using the assumed fuel density of 6.2 pounds/gallon). On the other hand, a study sponsored by the American Petroleum Institute found that more spills occurred at gas stations with stage II recovery [20].

We have recently performed laboratory experiments to examine the fate of liquid spill droplets. Following our previous protocol [21•], we spilled fuel droplets onto small concrete samples and measured the mass added to the concrete as a function of time. This added mass is the sum of the masses of the sessile fuel droplet and the infiltrated fuel. Figure 2 shows results for diesel and gasoline. After a certain period of time, the sessile droplet vanishes and the measured mass levels off. The remaining mass represents the infiltrated portion. The evaporated mass can be obtained by subtracting the infiltrated mass from the initial droplet mass $m_{0}$. Evaporation is greater for gasoline, while infiltration is greater for diesel spills. This is because gasoline is more volatile than diesel. Diesel has therefore a higher potential for soil contamination because of the higher infiltrated mass.

Spilled fuel may move downward in liquid or vapor phase and potentially reach the groundwater table. The physical mechanisms that govern subsurface movement of spilled fuel are the same as for fuel released due to LUST, except that spilled fuel must first penetrate relatively impermeable pavement underneath fuel-dispensing stations. Gasoline and diesel will not penetrate the groundwater table as a liquid, because they have densities lower than that of water. Released fuel may also evaporate within the sediment, and a portion of it will move downward as a vapor and potentially reach the groundwater table [22]. Whether the fuel reaches groundwater in liquid or vapor form, the fuel will then partition into groundwater and become a dissolved chemical that is carried away by molecular diffusion and groundwater flow and associated hydrodynamic dispersion [23]. Therefore, the spills can contaminate downstream drinking water wells [24]. Biodegradation can decrease contaminant concentrations significantly; however, its efficiency depends on many factors including the chemical composition of the fuel and the presence of suitable microbial species that can metabolize a given contaminant, bioavailability, and electron acceptor availability [25]. Partitioning of the contaminant into other phases will cause

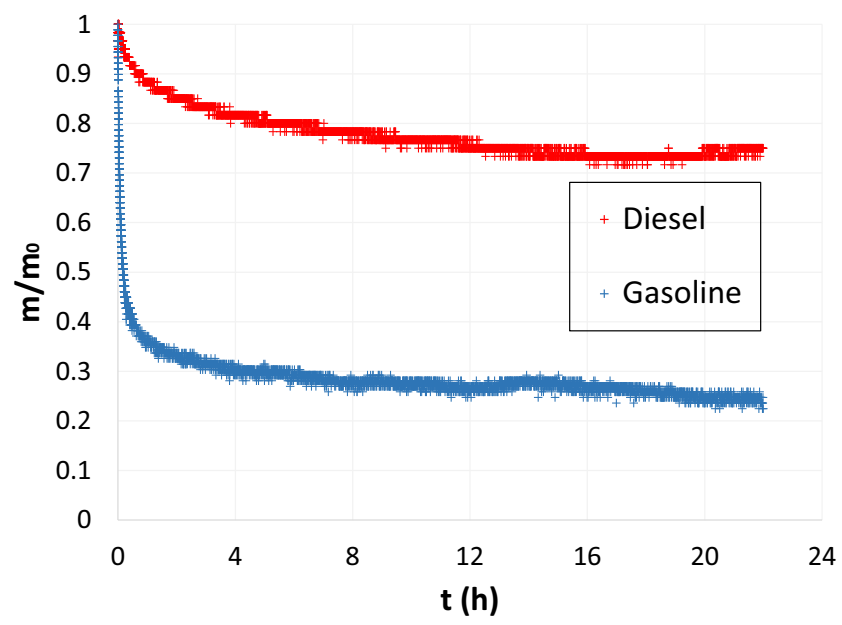

Fig. 2 Results from laboratory experiments, in which we spilled a mass $m_{0}=1 \mathrm{~g}$ of diesel or gasoline onto concrete samples. The measured mass $m$ represents the masses of the sessile droplet and infiltrated liquid 
retarded transport of the contaminant within groundwater. For instance, hydrophobic contaminants such as benzene tend to sorb to the sediment. For this reason, large-scale contamination of aquifers and associated adverse health effects due to the ingestion of contaminated drinking water from these aquifers are often considered a lesser concern for hydrophobic contaminants [16].

Stocking et al. [26] evaluated the potential of groundwater contamination due to small one-time releases of liquid gasoline. In a case study, they assumed a spill volume much bigger than the ones typically measured by the study of gas stations in California [19], i.e., $0.5 \mathrm{~L}$, and they concluded the risk to groundwater to be small. This analysis, however, did not include consideration of a key mechanism for fuel spillage; namely, that much smaller droplets are typically released during vehicle refueling [19]. To address this question, Hilpert and Breysse [21 •] calculated cumulative spill volumes due to repeated small spillages that occur at gasoline-dispensing facilities and estimated that a gas station selling about 400,000 L of gasoline per month would spill at least $150 \mathrm{~L}$ each year. They also developed a model that shows that the fraction of spilled gasoline that infiltrates into the pavement increases as the droplet size decreases. Therefore, repeated small spills could be of greater concern for groundwater contamination than an instantaneous release of the cumulative spill volume; thus, a risk to groundwater may not be as small as previously estimated.

Laboratory experiments and modeling have shown that gasoline from small-volume spills can infiltrate into the concrete that usually covers the ground underneath gasolinedispensing stations - despite the low permeability of concrete and the high vapor pressure of gasoline [21•]. It is unlikely that liquid fuel fully penetrates a concrete slab to contaminate the underlying natural subsurface due to the low permeability of concrete [27], although preferential pathways for fluid flow such as cracks and faulty joints between concrete slabs can allow for such liquid penetration. It has been hypothesized that evaporation of infiltrated gasoline and subsequent downward migration of the vapor through the concrete may lead to contamination of underlying sediment and groundwater [21•]. Consistent with these two proposed pathways of subsurface contamination, soil/sediment underneath concrete pads of a gas station in Maryland was contaminated by diesel oil and gasoline (leaky piping could have also contributed to the contamination) [28].

Runoff water that flows over pavement can also get contaminated with hydrocarbons spilled onto the pavement [29-31], and such contamination has specifically been linked to gas stations [32-34]. If a spill occurs while runoff occurs, the hydrocarbon can be expected to float on top of the water sheet, because gasoline, diesel oil, and lubricants are typically less dense than water (light non-aqueous phase liquids or LNAPLs). While runoff water is not directly ingested, it is funneled into the stormwater drainage system, and may be released to natural water bodies, often without treatment. Whereas volatilization decreases contaminant levels in the stormwater within hours depending on the exact environmental conditions [35], and biodegradation will further decrease levels, significantly contaminated stormwater might be released to natural water bodies if they are close by. Finally, fuel spilled at marine gas stations may directly enter natural water bodies.

\section{Vapor Fuel Releases}

Fuel evaporative losses have received more attention than liquid fuel spills (even though they are related) $[6,36]$. These losses are related to the fact that the headspace above liquid fuel in vehicle and storage tanks tends to approach thermodynamic equilibrium with the liquid. Consequently, almost saturated gasoline vapors can be released to the atmosphere when tanks are refueled, unless a suitable vapor recovery system is in place. Since saturated gasoline vapors have a density that is three to four times larger than the one of air, i.e., $4 \mathrm{~kg} / \mathrm{m}^{3}$, and the density of liquid gasoline is about $720 \mathrm{~kg} / \mathrm{m}^{3}$ [37], about $0.5 \%$ of liquid gasoline dispensed to a tank is released to the atmosphere if the entire headspace is in equilibrium with the liquid fuel. This is true for any type of tank, whether it is a vehicle tank, a canister, an underground storage tank (UST), or an above-storage tank. The percentage loss is less if a tank received clean air relatively recently, e.g., when the fuel level in a storage tank drops because of gasoline-fuel dispensing.

It is important to note that vapor recovery at the nozzle can cause vapor releases at the storage tank, because vapors recovered at the nozzle are typically directed into the storage tank. The storage tank, in turn, can "breathe" and potentially release recovered vapors immediately or at a later time. A tank sucks in relatively uncontaminated air as the liquid fuel level drops in the tank due to vehicle refueling, and it releases vapors through the vent pipe into the atmosphere if the gas pressure increases and exceeds the cracking pressure of the pressure/vacuum valve, when fuel evaporates into unequilibrated gas in the headspace.

As discussed in the "Liquid Fuel Spills" section above, we note that liquid spills also contribute to air pollution because spilled droplets form sessile droplets on pavement that can then evaporate into the atmosphere. On concrete, most of spilled gasoline droplets evaporate into the atmosphere (Fig. 2). This, however, does not mean that the small fraction that infiltrates into the concrete is not of concern.

\section{Exposure and Risks to Human Populations}

Gas stations exist as part of the built environment and are widely distributed across communities. As a result, they may be surrounded by residential dwellings, businesses, and other 
buildings such as schools. Operation of gas stations may thus create opportunities for a variety of human populations to be exposed to vapors during station tank filling and vehicle refueling. These human populations can be broadly grouped into three groups: populations exposed occupationally as a result of employment in various capacities at the service station; those exposed as customers engaging in vehicle refueling; and those passively exposed either by residing, attending school, or working near the refueling station. The exposures to benzene and other components of refueling vapors and spills experienced by these populations vary based on a number of factors, including the size and capacity of the refueling station, spatial variation in pollutant concentrations in ambient air, climate, meteorological conditions, time spent at varying locations of the service station, changing on-site activity patterns, physiological characteristics, and the use of vapor recovery and other pollution prevention technologies.

Employees at service stations (such as pump attendants, on-site mechanics, and garage workers) are among those with greatest exposure to benzene originating from gas stations [3]. These receptors spend the most time on site (potentially reflecting approximately $40 \mathrm{~h}$ per week, for decades) and intermittently spend time where vapors from the pump are at their highest concentrations, with benzene concentrations measuring between 30 and $230 \mathrm{ppb}$ in the breathing zone [38-40]. Gas station patrons can also be exposed to vapors when refueling. Compared to station employees, their exposures are brief and transient. A Finnish study reported a median time spent refueling of approximately $1 \mathrm{~min}$, whereas 3 min was the median duration in the USA [41, 42]. The same US study reported an average benzene personal exposure concentration at the pump of $910 \mathrm{ppb}$, with the strongest predictors of benzene levels being fuel octane grade, duration of exposure, and season [42].

Those occupying residences, businesses, and other structures neighboring gas stations can also be exposed to fuel vapors originating in the gas station, though typically at lower concentrations than those measured at the pump. While vapor concentrations will drop as the distance from the service station increases, exhaust fumes from waiting customers and fuel delivery trucks can also contribute to vapors in proximity to gas stations. A small number of studies have examined benzene concentrations at the fenceline of the service station and beyond. A study published by the Canadian petroleum industry found average benzene concentrations of 146 and $461 \mathrm{ppb}$ at the gas station property boundary in summer and winter, respectively [43]. A South Korean study examined outdoor and indoor benzene concentrations at numerous residences within $30 \mathrm{~m}$ and between 60 and $100 \mathrm{~m}$ of gas stations and found median outdoor benzene concentrations of 9.9 and $6.0 \mu \mathrm{g} / \mathrm{m}^{3}$ (about 3.1 and $1.9 \mathrm{ppb}$ ), respectively. Median indoor concentrations at these locations were higher, reaching 13.1 and $16.5 \mu \mathrm{g} / \mathrm{m}^{3}$ (about 4.1 and $5.2 \mathrm{ppb}$ ), respectively
[44]. Another study found median ambient benzene levels of $1.9 \mathrm{ppb}$ in houses both $<50$ and $>100 \mathrm{~m}$ from a service station [45]. Yet, another study [46] found that benzene and other gasoline vapor releases from service stations can be discerned from traffic emissions as far as $75 \mathrm{~m}$ from service stations and that the contribution of service stations to ambient benzene is less important in areas of high traffic density. This is because vehicle exhaust is usually the most abundant volatile organic compound (VOC) in urban areas, often followed by gasoline vapor emissions from fuel handling and vehicle operation [47].

Beyond contact with surface-level gasoline vapors, fuel releases may result in other exposure pathways. Soil and groundwater contamination is common at gas stations. Drinking water wells proximate to gas stations, which in rural areas are often the only drinking water source, can become contaminated, potentially exposing well users to benzene and other chemicals $[48,49]$. In addition, runoff from rain and other weather events can carry spilled hydrocarbons, which can contaminate surface waters; those using surface waters, either recreationally or for other purposes, may be exposed to these contaminants through dermal contact or incidental ingestion.

In the USA, the Environmental Protection Agency (EPA) regulates releases of benzene under the Clean Air Act as a hazardous air pollutant, and benzene is listed as number 6 on the 2005 priority list of hazardous substances under the Comprehensive Environmental Response, Compensation, and Liability Act and any release greater than 10 pounds triggers a reporting requirement. Different quantitative toxicity metrics exist for benzene inhalation. The EPA Integrated Risk Information System (IRIS) has published a reference concentration of $0.03 \mathrm{mg} / \mathrm{m}^{3}$ (about $9.4 \mathrm{ppb}$ ), corresponding to decreased lymphocyte counts [50], whereas the NIOSH recommended exposure limit (REL) is a time-weighted average concentration (for up to a 10-hour workday during a 40-hour workweek) of $0.319 \mathrm{mg} / \mathrm{m}^{3}$ (about $100 \mathrm{ppb}$ ) [51].

While research attention has been paid to measurement of gasoline vapor constituent concentrations in air at and near service stations, less is known about the health consequences faced by those that are exposed to gasoline vapors. Of the limited literature examining these exposures, service station workers have received the greatest attention, and exposure is often assessed as a function of job title, rather than specific measurements of vapor constituent concentrations. An older study looking broadly at leukemia incidence in Portland, Oregon, found that gas station workers were at significantly increased risk for lymphocytic leukemia [52]. A proportionate mortality ratio analysis of all deaths recorded in New Hampshire among white men from 1975 to 1985 found elevated leukemia mortality in service station workers and auto mechanics [53]. The type of leukemia was not specified. An Italian occupational cohort study of refilling attendants that examined risks among workers at smaller gas stations reported 
non-significant increases in mortality for non-Hodgkin's lymphoma and significantly elevated mortality for esophageal cancer in men, as well as increased brain cancer mortality in both sexes [54]. A different cohort of 19,000 service station workers in Denmark, Norway, Sweden, and Finland examined an array of cancer end points and found increased incidence for multiple sites (nasal, kidney, pharyngeal, laryngeal, and lung) among workers estimated to be occupationally exposed to benzene in the range of $0.5-1 \mu \mathrm{g} / \mathrm{m}^{3}(0.16-0.31 \mathrm{ppb})$. Nonsignificant increased incidence was found for acute myeloid leukemia in men and for leukemia different from acute myeloid leukemia and chronic lymphocytic leukemia in women [55]. A case-control study of multiple occupations including subjects from the USA and Canada found significant increases in rates of total leukemia and acute myeloid leukemia but not acute lymphocytic leukemia in gas station attendants [56]. A 2015 review of studies examining potential relationships between benzene exposures and hematopoietic and lymphatic cancers among vehicle mechanics yielded inconclusive results, although it suggested that if an effect was to exist, it would be small and difficult to rigorously ascertain with existing epidemiologic methods [57].

The health consequences of nearby residents of gas stations have not been studied. However, it is known that contaminated groundwater can affect large numbers of people if the groundwater is used as drinking water, as was the case in Camp Lejeune (North Carolina, USA) where thousands were exposed to a range of chemicals including gasoline released from LUSTs [58]. A study of Pennsylvania residents residing in close proximity to a large gasoline spill from a LUST found evidence of increased leukemia risks $[49,59 \bullet \cdot]$. The health consequences of chronic fuel releases at gas stations that can, for example, occur due to ingestion of contaminated groundwater, fuel vapor intrusion from contaminated soil and groundwater into dwellings [60], and atmospheric vapor releases during fuel transfer and storage have not been studied. While limited measurements of ambient concentrations of vapor constituents in communities were identified, literature searches did not identify studies of the health consequences of inhalation exposures to gasoline vapors among community residents [61].

\section{Pollution Prevention}

Pollution prevention technologies have been developed that can efficiently reduce the releases of unburned fuel to the environment that routinely occur during fuel storage and transfer (see Fig. 3):

1. Stage I vapor recovery collects vapors that would be expelled from USTs during fuel delivery [62]. Without stage I vapor recovery, about $80 \mathrm{~kg}$ of gasoline vapor would be released from a $40 \mathrm{~m}^{3}$ UST if one assumes a saturated vapor density of $4 \mathrm{~kg} / \mathrm{m}^{3}[37]$ and vapors in the headspace

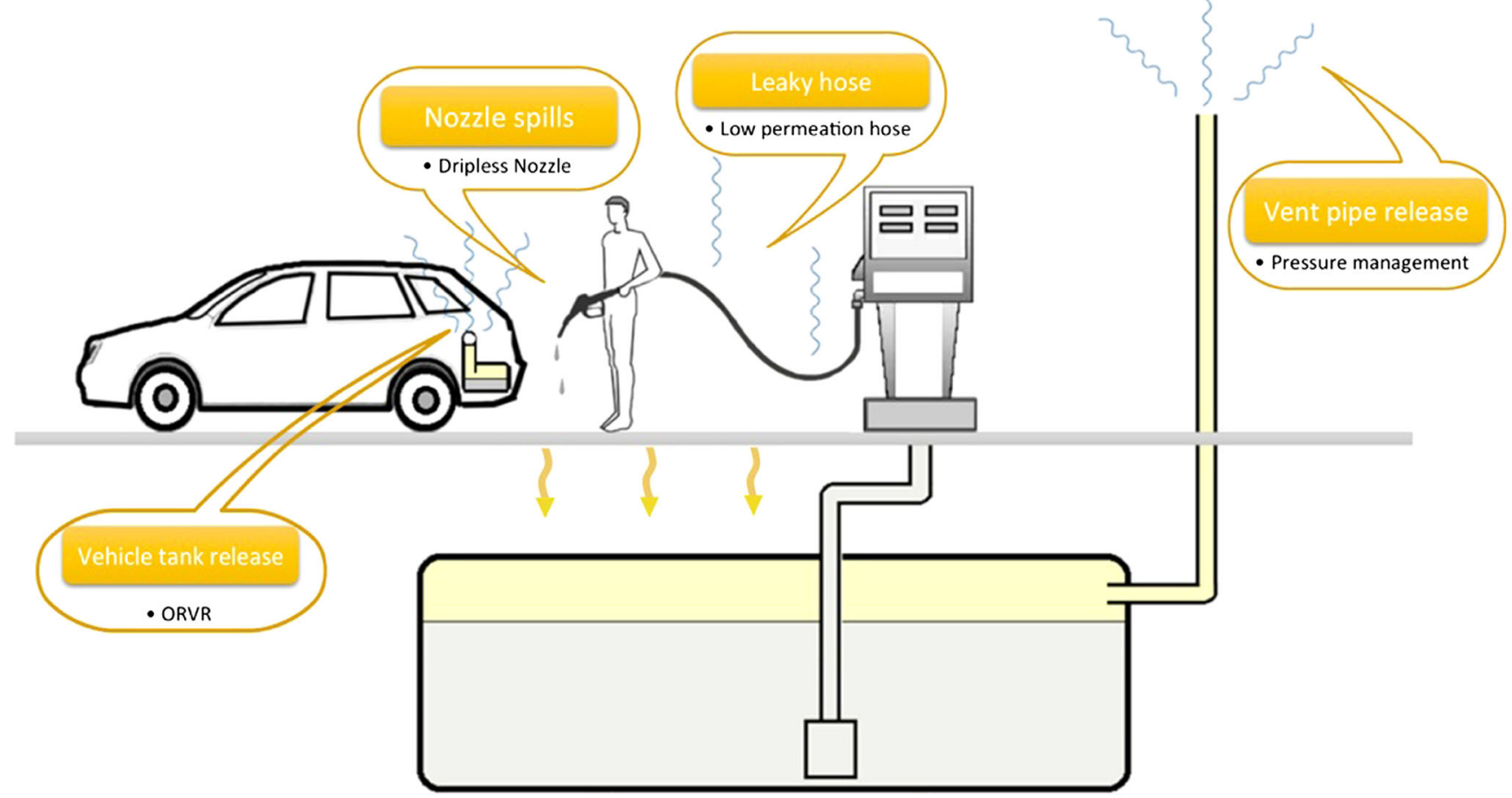

Fig. 3 There are several sources of chronic release of unburned fuel at gas stations that occur due to fuel storage and dispensing: vapor release through the vent pipe of the storage tank, vapor release from the vehicle tank during refueling, leaky dispensing hoses, liquid spills during vehicle refueling, and vapor emissions through evaporation of this spilled fuel. As indicated, suitable pollution prevention technology can minimize the releases. Onboard refueling vapor recovery (ORVR) 
to be at half saturation. Stage I vapor recovery can thus prevent substantial fuel vapor releases that would occur within a short period of time. Such releases might expose tanker truck drivers and persons in the proximity of a gas station to significant doses of fuel vapors. Stage I vapor recovery is accomplished by establishing a closed loop between the UST and the tanker truck. Through a fuel delivery hose, liquid fuel is pumped into the UST, while a vapor recovery hose directs vapors displaced from the UST into the headspace of the tanker truck. Stage I vapor recovery is currently required for high-throughput gas stations in all states in the USA and in most countries.

2. Stage II vapor recovery technology can efficiently collect vapors expelled from vehicle tanks during refueling, thereby minimizing personal exposure of customers and workers to fuel vapors during dispensing of gas [63]. Recovered vapors are directed into the UST. Two technologies for stage II vapor recovery have been developed, the vaccum-assist method and the balance method. In the vacuum-assist method, contaminant-laden air is actively removed/pumped from the nozzle into the UST. In the balance method, displaced vapors are passively withdrawn by connecting the vapor recovery hose to the inlet of the vehicle tank via an airtight seal. The pressure increase in the headspace of the vehicle tank provides a driving force that seeks to push the vapors into the storage tank. Stage II vapor recovery has been required in many states of the USA and in other countries, although there is currently an effort to decommission stage II vapor recovery (see below).

3. Technology development at the hose and nozzle level can also contribute to reduced fuel releases. Low-permeation hoses, for instance, limit the release of gasoline vapors through the wall of the refueling hoses [64]. Dripless nozzles have been developed to minimize liquid spills that occur when the nozzle is moved between the fill pipe and the dispensing unit.

4. Passenger vehicles and trucks can be equipped with onboard refueling vapor recovery (ORVR) systems which direct vapors that, during vehicle refueling, would be released to the atmosphere into an activated carbon-filled canister in the vehicle $[65,66]$. Collected vapors are later reintroduced into the vehicle's fuel system. However, canisters, motorcycles, and boats are not equipped with ORVR.

5. Impermeable liners underneath the concrete pads can reduce the risk of soil and groundwater contamination once environmental fuel releases, in liquid or vapor phase, have occurred. However, this technology might eventually result in air pollution, because liquid fuel that is hindered from moving downward in the concrete pad will tend to saturate the pavement and eventually evaporate into the atmosphere.

6. Finally, unburned fuel vapor can be released from an UST when the tank pressure exceeds the cracking pressure of the pressure/vacuum valve and it can be prevented by two pressure management techniques, burning or separation of air and fuel vapors. Released air/fuel vapors can be burned, however, which results in the release of combustion-related pollutants into the atmosphere. Alternatively, a semi-permeable membrane can be used to separate the air from the fuel vapors. Depressurization of the tank is then achieved by releasing the relatively clean air through the pressure/vacuum valve to the atmosphere.

When it comes to evaluating the efficiency of vapor recovery during liquid transfer between tanks, it is of upmost importance to consider potential releases from all tanks; they form a system. Otherwise, the overall efficiency of stage II vapor recovery cannot be understood. For instance, stage II vapor recovery based on the vacuum-assist method can negatively interfere with ORVR. In that case, no vapors are released from the vehicle tank and the stage II pump draws relatively clean air from the atmosphere into the storage tank. In the UST, this air will become saturated with fuel vapors that evaporate from the stored fuel. This results in pressurization of the UST and release of contaminant-laden air if the tank pressure exceeds the cracking pressure of the pressure/vacuum valve of the UST. This might occur immediately or at a later point in time. However, there are stage II systems that do not negatively interfere with ORVR including the balance method.

Estimates for the efficiency of pollution technologies are usually provided by the manufacturers. However, adoption of these technologies by gas station owners usually relies on the certification and quantification of efficiencies by independent parties. In the USA, the California Air Resources Board and EPA typically assume this role [36]. Consultants and environmental agencies have used these estimates to determine current releases of unburned fuel to the environment and to evaluate the effects of pollution prevention technology [67].

While many studies have found health benefits from pollution prevention technology intended to minimize chronic gasoline spills, these studies typically do not quantify overall financial benefits and costs. Instead, only equipment and maintenance cost are typically considered [68]. Adopting the new equipment can reduce fuel losses and reduce environmental cost and health risks. However, this new equipment comes with non-trivial upfront costs. It is therefore a concern that the related policy-making process of chronic fuel spills relies only on non-comprehensive cost estimates. Studies are needed that account for health care cost due to released pollutants and energy-saving benefits due to pollution prevention. Such econometric studies have, for example, been performed in the context of pollutant emissions from coal-fired power plant and commercial real estate development [69••, 70]. At times, there is also the perception that pollution prevention 
costs are only carried by the specific industry [71]. Adoption of the environmentally friendly technology could be slow when the firms have long equipment replacement cycles or when the firms do not have sufficient information to evaluate whether or not a switch to an environmentally friendly technology is in their private interests. It is, however, not clear that this apparent investment, in the form of prevention cost, might also be partly shouldered by customers and that this apparent cost might actually (at least in the long run) be beneficial to customers, gas station workers, nearby residents, and other populations that spend significant amounts of times in the proximity of gas stations (e.g., school children in nearby schools). Policy intervention is often expected to expedite the adoption of such environmental friendly technologies, in order to reduce the difference in the private and social values of adoption.

Efforts are currently underway that could potentially allow decommissioning stage II vapor recovery in the USA due to the widespread use of ORVR in the motor vehicle fleet [68]. However, the remaining legacy fleet without ORVR and all motorcycles and boats (lacking ORVR) can produce significant emissions during vehicle refueling, emissions that could be avoided by stage II vapor recovery. For the State of Maryland, it has been estimated that fuel consumption of nonORVR-equipped vehicles was about $10 \%$ in 2015 (Table 4 in [67]). These emissions can result in direct hydrocarbon exposures among vehicle owners during vehicle refueling as well as in passive exposure of other populations. A comprehensive cost analysis of the decommissioning of stage II recovery represents an opportunity to inform policy makers on their recommendation with regards to stage II recovery.

\section{Conclusions}

Even if only a small fraction of unburned fuel is lost during vehicle refueling and fuel storage, the cumulative release of fuel to the environment can be large if large total amounts of fuel are dispensed at gas stations. For instance, about $0.01 \%$ of fuel can be spilled during the refueling process and up to about $0.5 \%$ can be lost in vapor form if equilibrated gasoline vapors are released from a tank to the atmosphere during refueling (worst-case scenario). For a medium-size gas station, which sells $400,000 \mathrm{~L}$ of gasoline per month, this results in $480 \mathrm{~L}$ of spilled gasoline and in $24,000 \mathrm{~L}$ of liquid gasoline that is anually released in vapor form to the environment. Even though dilution can reduce concentrations of released contamination, research is needed to assess whether such releases represent an environmental health concern.

The potential for pollution prevention, moreover, is substantial. Technology has already been developed and partially employed that can efficiently decrease vapor losses and liquid spills. Particularly, when it comes to vapor losses, it is crucial to consider not only vapor recovery at the vehicle tank/nozzle but also at the storage tank, since vapors recovered at the nozzle are directed into the storage tank, from which they might be potentially released. While California has implemented the strictest regulations when it comes to preventing chronic hydrocarbon releases at gas stations, other highly industrialized states and nations do not employ the same standards for different reasons. For instance, pressure/vacuum valves on vent pipes of fuel storage tanks are not common in Canada, because they might freeze in the wintertime, potentially causing a tank implosion [6].

Relatively little research has been done on potential soil and groundwater contamination due to chronic releases of liquid fuel during vehicle refueling. Unlike catastrophic releases, such as LUST, chronic spills are not reported. Limited field investigations suggest that spilled fuel may penetrate concrete underneath dispensing pads to contaminate underlying sediment. However, it is possible that such soil contamination occurs routinely over the life span of a gas station and that this contamination pathway is masked or erroneously explained by leaks in the piping from the USTs to the dispensers. Overall, large-scale soil and groundwater contamination by fuel appears to be a lesser problem, because many of the toxic compounds in fuel are hydrophobic (including BTEX) and can therefore be expected not to travel too far in groundwater. However, customers, gas station workers, and nearby residents may get exposed to the hydrocarbons if groundwater is used as a drinking water supply or if fuel vapor intrusion in dwellings occurs.

Health effects of living near gas stations are not well understood. Adverse health impacts may be expected to be higher in metropolitan areas that are densely populated. Particularly affected are residents nearby gas stations who spend significant amounts of time at home as compared to those who leave their home for work because of the longer period of exposure. Similarly affected are individuals who spend time close to a gas station, e.g., in close by businesses or in the gas station itself. Of particular concern are children who, for example, live nearby, play nearby, or attend nearby schools, because children are more vulnerable to hydrocarbon exposure [72].

Potential future changes in fuel composition might pose new environmental health challenges as there is a history of adding even large amounts of toxic substances to fuel (Table 1). Changes in fuel composition could occur due to an increasing usage of biofuels, or to comply with air quality standards, which might also change over time. Chemicals newly added to fuel or changes in chemical concentrations can have unforeseen ramifications. One could argue that future fuel composition changes will be performed with more care; however, it was only in the 1990s, decades after the Safe Drinking Water Act (SDWA) was passed in 1974, that MTBE was added to gasoline without critically evaluating its transport behavior in groundwater and toxicity, a mistake which 
nowadays is considered avoidable [73]. Interestingly, ethanol, which has largely replaced MTBE, can inhibit biodegradation of BTEX, which is not the case for MTBE [74]. Given the complexities of chemical fate and transport in the environment and the potential for insufficient toxicity testing, using appropriate pollution prevention technology that minimizes release of unburned chemicals with known and unknown adverse health effects during fuel storage and transfer seems a wise, long-term, and cost effective idea given ever-changing fuel compositions.

Finally, employing efficient pollution prevention technology might be economically advantageous. The evaluation of economic benefits of pollution prevention technology needs to account not only for the cost of implementation and maintenance of such technology but also for public health burdens due to released pollutants and energy-saving benefits due to valuable hydrocarbons not wastefully released to the environment.

Acknowledgments This work was funded by a seed grant from the Environment, Energy, Sustainability and Health Institute at Johns Hopkins University.

\section{Compliance with Ethics Guidelines}

Conflict of Interest Markus Hilpert, Bernat Adria Mora, Jian Ni, Ana Rule, and Keeve Nachman declare that they have no conflict of interest.

Human and Animal Rights and Informed Consent This article does not contain any studies with human or animal subjects performed by any of the authors.

\section{References}

Papers of particular interest, published recently, have been highlighted as:

- Of importance

•. Of major importance

1. Wang $Z$ et al. Characteristics of spilled oils, fuels, and petroleum products: 1. composition and properties of selected oils. United States Environmental Protection Agency. Report No.: EPA/600/R03/072, 2003.

2. IARC, IARC monographs on the evaluation of carcinogenic risks to humans. Vol. 100F. 2012.

3. Karakitsios SP et al. Assessment and prediction of exposure to benzene of filling station employees. Atmospheric Environment. 2007;41(40):9555-69.

4. Javelaud B et al. Benzene exposure in car mechanics and road tanker drivers. International Archives of Occupational and Environmental Health. 1998;71(4):277-83.

5. U.S. Energy Information Administration. How much gasoline does the United States consume? 2015 [cited 2015 July 20]; Available from: http://www.eia.gov/tools/faqs/faq.cfm?id=23\&t=10.

6. Statistics Canada. Gasoline evaporative losses from retail gasoline outlets across Canada 2009. Environment Accounts and Statistics Analytical and Technical Paper Series, 2012.
7. Dowd RM. Leaking underground-storage tanks. Environmental Science \& Technology. 1984;18(10):A309-9.

8. Centers for Disease Control and Prevention. Facts about benzene. 2015 Available from: http://www.bt.cdc.gov/agent/benzene/basics/ facts.asp.

9. Nadim $\mathrm{F}$ et al. United States experience with gasoline additives. Energy Policy. 2001;29(1):1-5.

10. Weaver JW, Exum LR, Prieto LM. Gasoline composition regulations affecting LUST sites. U.S. Environmental Protection Agency Office of Research and Development Washington, DC 20460, 2010. Report No.: EPA 600/R-10/001.

11. Needleman HL. The removal of lead from gasoline: historical and personal reflections. Environmental Research. 2000;84(1):20-35.

12. Grandjean P, Landrigan PJ. Developmental neurotoxicity of industrial chemicals. Lancet. 2006;368(9553):2167-78.

13. Thomas VM. The elimination of lead in gasoline. Annual Review of Energy and the Environment. 1995;20:301-24.

14. U.S. Environmental Protection Agency. National Ambient Air Quality Standards for ozone; final rule. Fed Reg. 2008;73:16436514.

15. U.S. Environmental Protection Agency, Achieving clean air and clean water: The report of the blue ribbon panel on oxygenates in gasoline, 1999.

16. Squillace PJ et al. Review of the environmental behavior and fate of methyl tert-butyl ether. Environmental Toxicology and Chemistry. 1997;16(9):1836-44.

17. U.S. Energy Information Administration, Eliminating MTBE in gasoline in 2006. 2006.

18. U.S. Environmental Protection Agency, Fuel oxygenates (MTBE, TBA, and ethanol). 2015.

19. Morgester JJ, Fricker RL, Jordan GH. Comparison of spill frequencies and amounts at vapor recovery and conventional service stations in California. Journal of the Air \& Waste Management Association. 1992;42(3):284-9.

20. Mueller EA. A survey and analysis of liquid gasoline released to the environment during vehicle refueling at service stations. Washington, DC: American Petroleum Institute; 1989.

21. Hilpert M, Breysse PN. Infiltration and evaporation of small hydrocarbon spills at gas stations. Journal of Contaminant Hydrology. 2014;170:39-52. This study examines for the first time the fate and transport of small fuel droplets spilled during vehicle refueling.

22. Dakhel $\mathrm{N}$ et al. Small-volume releases of gasoline in the vadose zone: impact of the additives MTBE and ethanol on groundwater quality. Environmental Science \& Technology. 2003;37(10):212733.

23. Charbeneau R.J., Groundwater hydraulics and pollutant transport 2006: Waveland Press, Inc.

24. Grady, S. and G. Casey, Occurrence and distribution of methyl tertbutyl ether and other volatile organic compounds in drinking water in the northeast and mid-Atlantic regions of the United States, 1993-98. Water Resources Investigations Report WRIR 00-4228. Geological Survey, U.S., 2001.

25. Leahy JG, Colwell RR. Microbial-degradation of hydrocarbons in the environment. Microbiological Reviews. 1990;54(3):305-15.

26. Stocking, A.S., et al., Evaluation of fate and transport of methyl tertiary butyl ether (MTBE) in gasoline following a small spill. In: Stanley, Anita, (eds.) Petroleum hydrocarbons and organic chemicals in ground water-prevention, detection, and remediation, Houston, Tex., Nov. 17-19, 1999. Proceedings.: National Ground Water Association, and American Petroleum Institute, 1999: p. 229-246.

27. Jacobs P. Permeabilität und Porengefüge Zementgebundener Werkstoffe. ETH Zürich: Switzerland; 1994.

28. Aria Environmental Inc., Underground Storage Tank Closure Report Chesapeake House - Exxon Facility (Northern Service 
Station) I-95 Travel Plaza, North East, Cecil County, Maryland, 2014, Maryland Transportation Authority.

29. Latimer JS et al. Sources of petroleum-hydrocarbons in urban runoff. Water Air and Soil Pollution. 1990;52(1-2):1-21.

30. Ohe T, Watanabe T, Wakabayashi K. Mutagens in surface waters: a review. Mutation Research-Reviews in Mutation Research. 2004;567(2-3):109-49.

31. Hoffman EJ et al. Urban runoff as a source of polycyclic aromatichydrocarbons to coastal waters. Environmental Science \& Technology. 1984;18(8):580-7.

32. Borden RC, Black DC, McBlief KV. MTBE and aromatic hydrocarbons in North Carolina stormwater runoff. Environmental Pollution. 2002;118(1):141-52.

33. Garcia MR et al. Assessment of polycyclic aromatic hydrocarbon influx and sediment contamination in an urbanized estuary. Environ Monit Assess. 2010;168(1-4):269-76.

34. Khan E, Virojnagud W, Ratpukdi T. Use of biomass sorbents for oil removal from gas station runoff. Chemosphere. 2004;57(7):681-9.

35. U.S. Environmental Protection Agency. Technical factsheet on: Benzene. 2015 Available from: http://www.epa.gov/ogwdw/pdfs/ factsheets/voc/tech/benzene.pdf.

36. CARB. Vapor Recovery Program. 2015 Available from: http:// www.arb.ca.gov/vapor/vapor.htm.

37. International Chemical Safety Cards (ICSC). ICSC \#: 1400. 2015 Available from: http://www.cdc.gov/niosh/ipcsneng/neng1400. html.

38. van Wijngaarden E, Stewart PA. Critical literature review of determinants and levels of occupational benzene exposure for United States community-based case-control studies. Applied Occupational and Environmental Hygiene. 2003;18(9):678-93.

39. Hartle R. Exposure to methyl tert-butyl ether and benzene among service station attendants and operators. Environmental Health Perspectives. 1993;101 Suppl 6:23-6.

40. Periago JF, Zambudio A, Prado C. Evaluation of environmental levels of aromatic hydrocarbons in gasoline service stations by gas chromatography. Journal of Chromatography A. 1997;778(12):263-8.

41. Vainiotalo $\mathrm{S}$ et al. Customer exposure to MTBE, TAME, C6 alkyl methyl ethers, and benzene during gasoline refueling. Environmental Health Perspectives. 1999;107(2):133-40.

42. Egeghy PP, Tornero-Velez R, Rappaport SM. Environmental and biological monitoring of benzene during self-service automobile refueling. Environmental Health Perspectives. 2000;108(12): 1195-202.

43. Akland GG. Exposure of the general population to gasoline. Environmental Health Perspectives. 1993;101 Suppl 6:27-32.

44. Jo W-K, Moon K-C. Housewives' exposure to volatile organic compounds relative to proximity to roadside service stations. Atmospheric Environment. 1999;33(18):2921-8.

45. Jo W-K, Oh J-W. Exposure to methyl tertiary butyl ether and benzene in close proximity to service stations. Journal of the Air \& Waste Management Association. 2001;51(8):1122-8.

46. Terrés IMM et al. Assessing the impact of petrol stations on their immediate surroundings. Journal of Environmental Management. 2010;91(12):2754-62.

47. Watson JG, Chow JC, Fujita EM. Review of volatile organic compound source apportionment by chemical mass balance. Atmospheric Environment. 2001;35(9):1567-84.

48. Wallace LA. The exposure of the general population to benzene. Cell Biology and Toxicology. 1989;5(3):297-314.

49. Patel AS et al. Risk of cancer as a result of community exposure to gasoline vapors. Archives of Environmental Health. 2004;59(10): 497-503.

50. U.S. Environmental Protection Agency. Benzene (CASRN 71-432). 2015 Available from: http://www.epa.gov/iris/subst/0276.htm.
51. National Institute for Occupational Safety and Health. NIOSH Pocket Guide to Chemical Hazards: Benzene. 2015 Available from: http://www.cdc.gov/niosh/npg/npgd0049.html.

52. Morton W, Marjanovic D. Leukemia incidence by occupation in the Portland-Vancouver metropolitan area. American Journal of Industrial Medicine. 1984;6(3):185-205.

53. Schwartz E. Proportionate mortality ratio analysis of automobile mechanics and gasoline service station workers in New Hampshire. American Journal of Industrial Medicine. 1987;12(1): 91-9.

54. Lagorio, S., et al. Mortality of filling station attendants. Scand Journal Work Environ Health 1994: 331-338.

55. Lynge $\mathrm{E}$ et al. Risk of cancer and exposure to gasoline vapors. American Journal of Epidemiology. 1997;145(5):449-58.

56. Terry PD et al. Occupation, hobbies, and acute leukemia in adults. Leukemia Research. 2005;29(10):1117-30.

57. Hotz P, Lauwerys RR. Hematopoietic and lymphatic malignancies in vehicle mechanics. Critical Reviews in Toxicology. 1997;27(5): 443-94.

58. Savitz, D.A.e.a., Contaminated water supplies at Camp Lejeune: assessing potential health effects 2009: National Academies Press.

$59 . \bullet$ Talbott EO et al. Risk of leukemia as a result of community exposure to gasoline vapors: a follow-up study. Environmental Research. 2011;111(4):597-602. This study suggests a possible association between chronic low-level benzene exposure due to a leaking underground storage tank and increased risk of leukemia among residents that live nearby a gas station.

60. Sanders PF, Hers I. Vapor intrusion in homes over gasolinecontaminated ground water in Stafford, New Jersey. Ground Water Monitoring and Remediation. 2006;26(1):63-72.

61. Caprino L, Togna GI. Potential health effects of gasoline and its constituents: a review of current literature (1990-1997) on toxicological data. Environmental Health Perspectives. 1998;106(3):115.

62. U.S. Environmental Protection Agency, Design criteria for Stage 1 vapor control systems-gasoline service stations. 1975.

63. U.S. Environmental Protection Agency, Technical guidancestage II vapor recovery systems for control of vehicle refueling emissions at gasoline dispensing facilities, Volume I: Chapters, 1991.

64. McPhee, J., Gasoline dispensing facility (GDF) balance hose permeation study, 2008, California Air Resources Board (CARB)

65. U.S. Environmental Protection Agency. Commonly asked questions about ORVR. Available from: http:/www.epa.gov/otaq/regs/ ld-hwy/onboard/orvrq-a.txt.

66. Musser, G. and H. Shannon, Onboard control of refueling emissions. 1986: p. SAE Technical Paper 861560.

67. Meszler Engineering Services, Stage II emission reduction benefits. Report to the Maryland Department of the Environment. 2012.

68. Federal Register, Air quality: widespread use for onboard refueling vapor recovery and stage II waiver. Final Rule by US Environmental Protection Agency. Federal Register 2012. 77(95).

69.• Currie J et al. Environmental health risks and housing values: evidence from 1,600 toxic plant openings and closings. American Economic Review. 2015;105(2):678-709. This study provides an empirical framework for understanding the effects and the health cost of toxic atmospheric emissions. The research design could be applied to pollution prevention at gas stations. Such analysis could provide important policy recommendation in order to mitigate this type of environmental risk.

70. Ni J. Environmental cost and economic benefit of commercial real estate development. Working Paper: Johns Hopkins University; 2015. 
71. Fong $\mathrm{M}$ et al. California dry cleaning industry technical assessment report. State of California Air Resources Board: Technical report; 2006.

72. Irigaray $\mathrm{P}$ et al. Lifestyle-related factors and environmental agents causing cancer: an overview. Biomedicine \& Pharmacotherapy. 2007;61(10):640-58.

73. McGarity TO. MTBE: a precautionary tale. Harvard Environmental Law Review. 2004;28(2):281-342.

74. Powers SE et al. The transport and fate of ethanol and BTEX in groundwater contaminated by gasohol. Critical Reviews in Environmental Science and Technology. 2001;31(1):79-123.
75. Jakobsson $\mathrm{R}$ et al. Acute myeloid-leukemia among petrol station attendants. Archives of Environmental Health. 1993;48(4):255-9.

76. U.S. Environmental Protection Agency, EPA requires phase-out of lead in all grades of gasoline. EPA press release - November 28, 1973. 1973.

77. U.S. Energy Information Administration (EIA), MTBE, oxygenates, and motor gasoline. 2000.

78. U.S. Environmental Protection Agency. Assessment of potential health risks of gasoline oxygenated with Methyl Tertiary Butyl Ether (MTBE). Washington, DC:Office of Research and Development, U.S. EPA. 1993. EPA/600/R-93/206. 